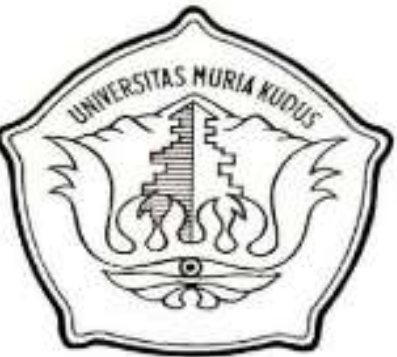

AN ANALYSIS OF MULTIPLE INTELLIGENCES

IN FOKUS ENGLISH STUDENT WORKSHEET FOR THE SIXTH GRADERS

IN THE ACADEMIC YEAR 2015/2016

By

DWI AISIN

NIM 201232102

ENGLISH EDUCATION DEPARTMENT

TEACHER TRAINING AND EDUCATION FACULTY

MURIA KUDUS UNIVERSITY 


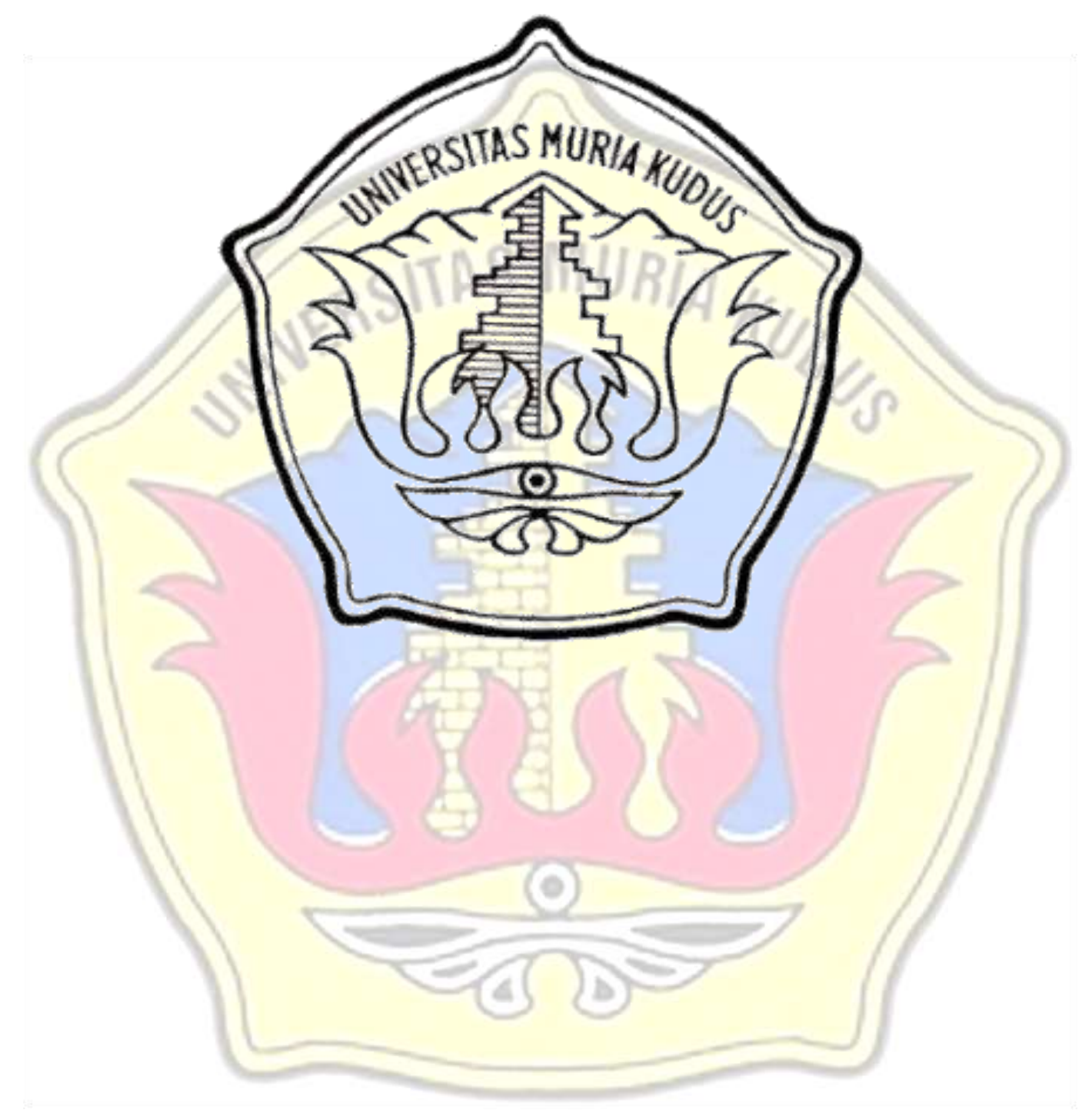


AN ANALYSIS OF MULTIPLE INTELLIGENCES

IN FOKUS ENGLISH STUDENT WORKSHEET

FOR THE SIXTH GRADERS

IN THE ACADEMIC YEAR 2015/2016

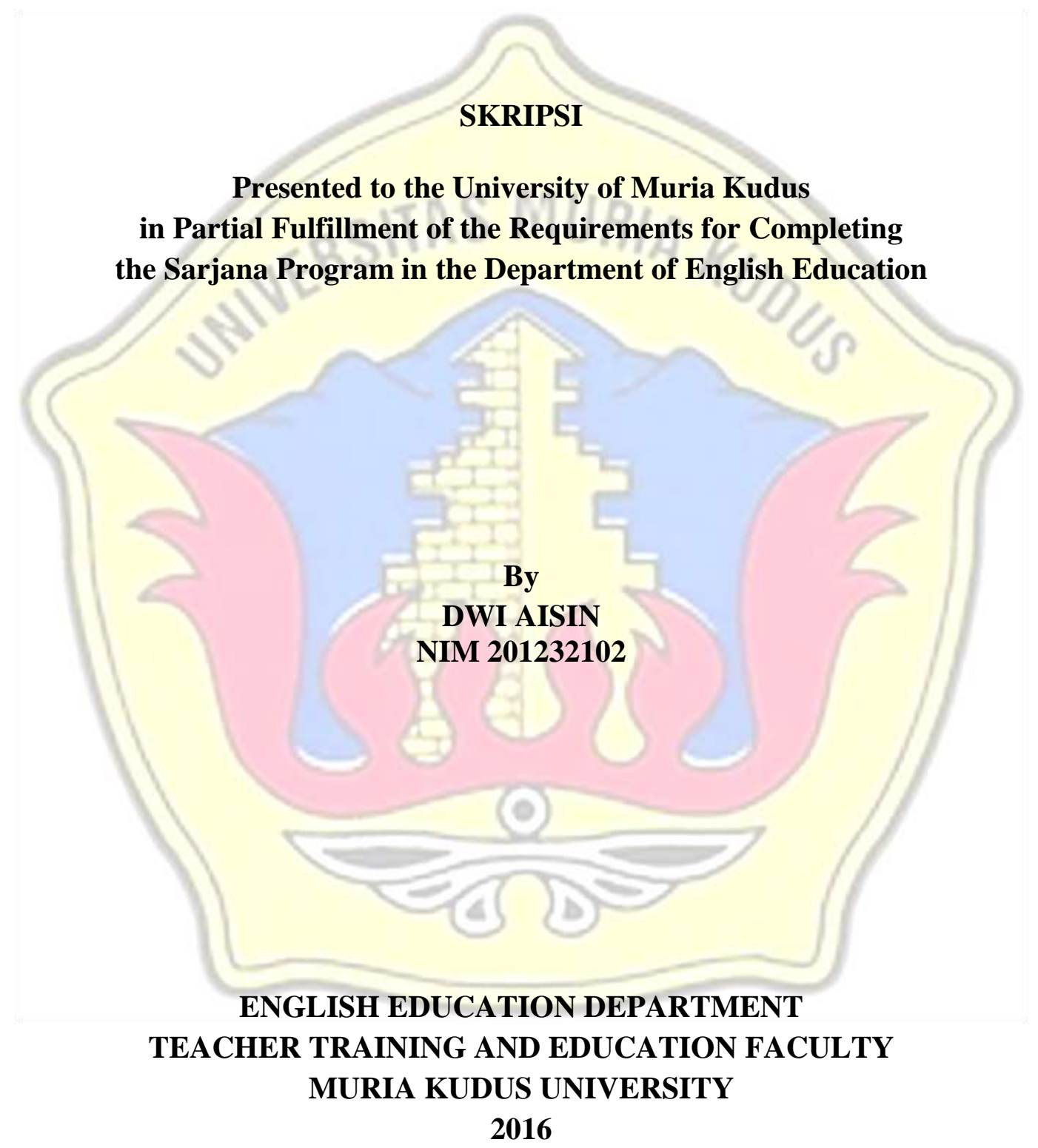




\section{MOTTO AND DEDICATION}

Motto

- When we respect to our teachers we will get the Berkah.

- Lazy can cancel your future.

- Praying is the basic of everything.

\section{ITAS MURIA}

\section{Dedication}

This skripsi is dedicated to:

- His beloved parents

- His brother and sister

- His family

- His friends 


\section{ADVISORS' APPROVAL}

This is to certify that the skripsi of Dwi Aisin (201232102) has been approved by the skripsi advisors for further approval by the Examining Committee.

Kudus, May $31^{\text {st }}, 2016$

Advisor I

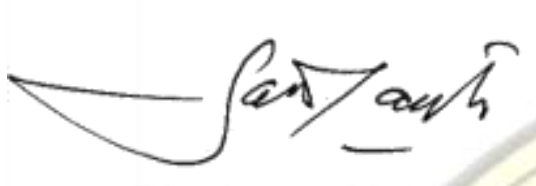

Rismiyanto,SS, M.Pd.

NIP/NIS. 0610701000001146

Kudus,May $31^{\text {st }}, 2016$

Advisor II

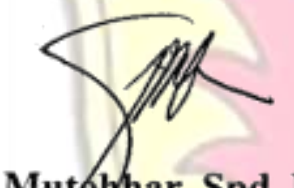

Mutolhar, Spd, M.Pd.

NUPXIS. 0610701000001204

Acknowledged by

Head of English Education Department

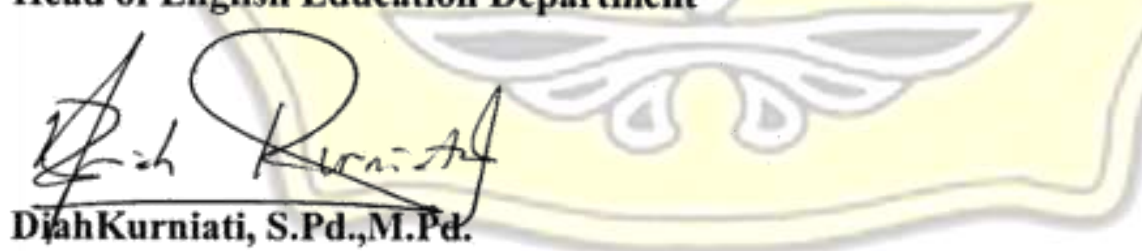

NIP/NIS, 0610701000001190 


\section{EXAMINERS' APPROVAL}

This is to certify that the skripsi of Dwi Aisin (201232102) has been approved by the

Examining Committee as a requirement for the Sarjana Degree in English Education.

Kudus, August $1^{\text {st }} 2016$

Skripsi Gxamining Committee:

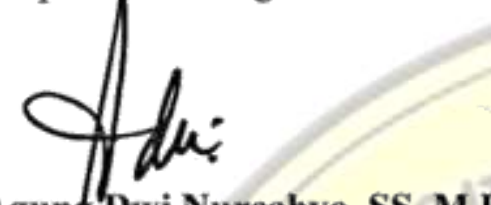

Agunk Dwi Nurcahyo, SS, M.Pd. S II, Chairperson

NIS. 0610701000001187

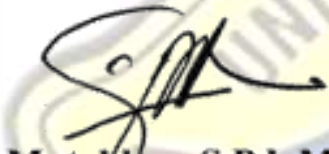

Mutohbar, S.Pd, M.Pd.

NIS. 0610701000001204

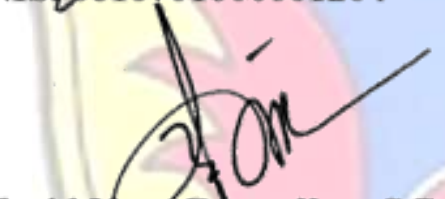

Farid Noor Rdmadlon, S.Pd, M.Pd.

NIS. 06107010ф0001227

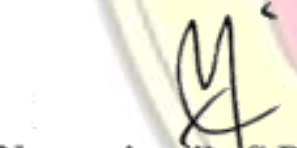

Nuraeningsih, S.Pd, M.Pd.

NIS. 0610701000001201

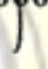

Acknowledged by

The Faculty of Teacher Training and Education

Dean,

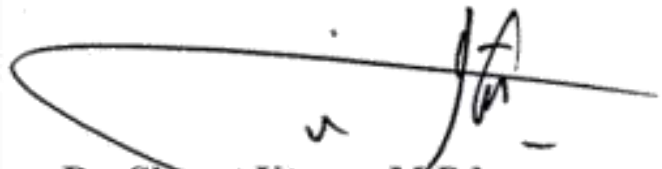

Dr. Slamet Utomo, M.Pd.

NIP. 196212191987031015 


\section{ACKNOWLEDGEMENT}

First of all, the writer would like to thank to Allah SWT who has given a chance, guidance, mercy, blessing, so that the writer can finish the research entitled "An Analysis of Multiple Intelligences in Fokus English Student Worksheet of The Sixth Graders in Academic Year 2015/2016"

In this occasion, the writer would like to express his sincere gratitude to:

1. Dr. Slamet Utomo, M.Pd as the dean of the Teacher Training and Education Faculty.

2. Diah Kurniati, S.Pd, M.Pd as the head of English Education Department of Teacher Training and Education Faculty of Muria Kudus University.

3. Rismiyanto,SS, M.Pd, as the first advisor, for all his invaluable time and patience in guiding the writer during the process of writing.

4. Mutohhar, Spd, M.Pd as the second advisor, for all his invaluable time and patience in guiding the writer during the process of writing.

5. All the English Department lecturers who have given much knowledge and have been teaching and guiding the writer patiently since the first year of the study at Muria Kudus University in 2012.

6. The headmaster of SDIT ROHMATUL UMMAH who has given permission to the writer to do the research.

7. The teachers of SDIT ROHMATUL UMMAH who guide and help the writer.

8. The writer's mother, father, and family who have given spirit, pray and support. 
9. The writer's friends ,Rudik ,Fisya ,Wahab ,Bagus ,Riski ,Iqlil ,Joe ,Afa ,Kang Barokah and All of santri Gondrong who help and guide the writer during the process of writing skripsi.

10. The writer would also like to express his gratitude to all friends and all people who always give supports in finishing this skripsi.

The writer realizes that there are still some lacking in his research proposal because of limitation knowledge and ability. However, he hopes that this research will be useful for the researcher himself, the students, the teachers, and the readers. 


\begin{abstract}
ABSTRAK
Aisin, Dwi. 2016. Analisis Multi Kecerdasan di Dalam Lembar Kerja Bahasa Inggris Fokus Kelas Enam di Tahun Ajaran 2015/2016. Skripsi. Pendidikan Bahasa Inggris, Fakultas Keguruan dan Ilmu Pendidikan, Universitas Muria Kudus. Pembimbing: (1) Rismiyanto,SS, M.Pd, (2).Mutohhar, Spd, M.Pd.
\end{abstract}

Kata Kunci: Multi Kecerdasan, Lembar Kerja Bahasa Inggris.

Pendidikan di perlukan oleh semua orang untuk mencapai cita-citanya dan dapat sukses di dalam hidupnya. Dalam kasus ini kecerdasan di artikan sebagai kemampuan intelektual yang di ukur dengan logika dalam memecahkan masalah. Untuk mengetahui kecerdasan siswa, sebagian besar guru mengunakan ulangan. Ulangan dapat di percaya dan hanya di ukur dari kecerdasan bahasa dan kecerdasaan matematika. Teori macam macam kecerdasan dapat membantu pendidik untuk mengajar siswa mereka, karena dengan mengetahui kecerdasan siswa guru bisa menyapaikan ilmu mereka. Dalam hal ini media dalam pembelajaran adalah lembar kerja siswa, yang mana siswa kelas enam harus memahami pelajaran bahasa inggris menggunakan lembar kerja siswa. Jadi, macam-macam kecerdasan di butuhkan oleh siswa dalam memahami pelajaran bahasa inggris.

Tujuan dari penelitian ini adalah untuk mengetahui jenis macam-macam kecerdasan yang di temukan di dalam lembar kerja siswa kelas enam yang di terbitkan oleh Sindunata dan bagaimana lembar kerja siswa memfasilitasi kecerdasan kecerdasan tersebut.

Ini adalah penelitian kualitatif. Penelitian ini menggambarkan jenis jenis kecerdasan yang di temukan dalam lembar kerja siswa kelas enam yang di terbitan oleh Sindunata di tahun ajaran 2015/2016. Dimana, data dari penelitian ini adalah macam-macam kecerdasan siswa dari 12 tema yang di temukan dalam lembar kerja siswa kelas enam yang di terbitkan oleh Sindunata di tahun ajaran 2015/2016. Sementara itu sumber data dari penelitian ini adalah lembar kerja siswa kelas enam SDIT Rohmatul Ummah.

Dari penilitian ini di peroleh: (i) jenis multi kecerdasan yang di temukan di dalam lembar kerja bahasa inggris kelas enam yang di terbitkan oleh Sindunata adalah $\mathrm{LW}=20, \mathrm{LM}=2, \mathrm{VS}=70, \mathrm{M}=0, \mathrm{IP}=37, \mathrm{IS}=35, \mathrm{BK}=9, \mathrm{~N}=0$ dan $\mathrm{E}=17$. (ii) lembar kerja siswa bahsa inggris memfasilitasi kecerdasaan siswa mengunakan percakapan yang sederhana.

Dari hasil penelitian ini, penulis menyarankan kepada (i) guru bahasa inggris kelas enam sebaiknya memilih lks yang berwarna, karena para siswa senang melihat gambar yang berwarna (ii) untuk guru bahasa inggris kelas enam sebaiknya mengajarkan siswa dengan mengunakan kecerdasan dalam memahami lks. (iii) untuk pembaca dapat menambah pengetahuan mereka dalam memahami kecerdasan dan dapat menambah informasi tentang teori bagaimana memilih lembar kerja yang layak. (iv) dalam penelitian ini peneliti masih kesulitan menemukan kecerdasan natural dan kecerdasan musik 


\begin{abstract}
Aisin, Dwi. 2016. An Analysis of Multiple Intelligences in Fokus English Student Worksheet of Sixth Graders in The Academic Year 2015/2016. Skripsi. English Education Department, Teacher Training and Education Faculty, Muria Kudus University, Advisor: (1) Rismiyanto,SS, M.Pd, (2).Mutohhar, Spd, M.Pd.
\end{abstract}

Key words: multiple intelligences, English student worksheet.

Education is needed for every people to reach the future and able to achieve success in their life. In this case the intelligence is understood as intellectual ability which emphasizes the logic in solving problems. To know the intelligences' of students, most of teachers use test. The test is reliable and only measure the intelligence of linguistic and logical mathematical intelligences. The multiple intelligences' theory can help educators to teach their students, because by knowing the intelligences of students' teachers can deliver their science. The media of teaching in this case is worksheets, in which the students' of six graders have to understand the English lesson using worksheet. So, multiple intelligences are needed by students to understand the English lesson.

The objectives of this research are to find out the types of multiple intelligences in the English student worksheet of six graders by Sindunata and how the English student worksheet facilitates those intelligences.

This is a qualitative research. It describes the types of multiple intelligences found in the English student worksheet of six graders by Sindunata in academic year 2015/2016. Whereas, the data of this research are the types of multiple intelligences from 12 themes that found in the English student worksheet of six graders by Sindunata in academic year 2015/2016. Meanwhile,bthe data source of this research is the English student worksheet which is published by Sindunata in the sixth graders of SDIT Rohmtaul Ummah.

From analyzing the data of this research, it was obtained that: (i) types of multiple intelligences found in English student worksheet of six graders published by Sindunata are linguistic word is 20 , linguistic mathematic is 2 , visual spatial is 70 , body kinesthetic is 9 , musical is 0 , interpersonal people is 37 , interpersonal self is 35 , naturalistic is 0 , and existential is 17 . (ii) The English student worksheet facilitates the types of multiple intelligences use simple dialogues.

From the result of this research, it was suggested for (i) The English teacher of six graders should select the English student worksheet, which has colorful pictures, because students like seeing pictures which have colorful. (ii) The English teacher should teach their students use the intelligences in understanding the English lesson using the worksheet. (iii) The reader can add their knowledge about understanding the intelligences and get the new information about the theory of how selecting a good worksheet. (iv) in this reach the writer still gets difficult to find the natural and musical intelligences in that worksheet. 
TABLE OF CONTENTS

\section{Page}

COVER

LOGO

TITLE 11

MOTTO AND DEDICATION

ADVISORS' APPROVAL

ACKNOWLEDGEMENT

ABSTRAK

ABSTRACT

TABLE OF CONTENTS

LIST OF TABLES

LIST OF APPENDICES

\section{....}

\section{CHAPTER I INTRODUCTION}

$1.1 \quad$ Background of the Research .................................................. 1

1.2 Statement of the Research ....................................................... 6

1.3 Objective of the Research .......................................................

1.4 Significance of the Research ..................................................... 7

1.5 Scope of the Research............................................................

1.6 Operational Definition ............................................................ 8

\section{CHAPTER II REVIEW TO RELATED LITERATURE}

2.1 Howard Gardner's Theory of Multiple Intelligences .................... 10

2.1.1 The Nine Multiple Intelligences' Theory ..................................... 11

2.1.2 The Implementation Teacher in Multiple Intelligences ................ 16

2.1.3 Developing Personal Intelligences in The Classroom................... 16

2.1.4 The Kinds of Learning Activities in Multiple Intelligences........... 18

2.2 The Basic Concepts of Student Worksheet .................................. 19

2.2.1 The Validity of Worksheet ...................................................... 21 
2.2.2 The Content Validity of Worksheet................................................ 22

2.2.3 The Eligibility Questions ............................................................. 23

2.2.4 The English Student Worksheet ............................................... 26

2.3 The Sixth Graders of SDIT Rohmatul Ummah ............................ 27

2.3.1 The Curriculum of SDIT Rohmatul Ummah.............................. . 27

2.3.2 The Purpose of Teaching English to Six Graders......................... 28

2.3.3 Review of Previous Research ................................................. 29

2.3.4 Theoretical Framework......................................................... . $\quad 30$

CHAPTER III METHOD OF THE RESEARCH

3.1 Design of the Research ...................................................... 32

3.2 Data and Data Source ......................................................... 32

3.3 Data Collection ................................................................... 33

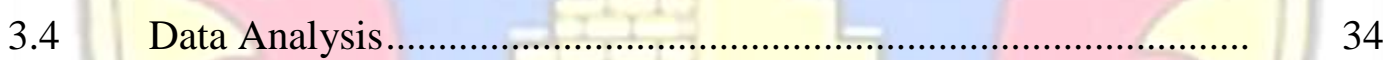

CHAPTER IV FINDING OF THE RESEARCH

4.1 Research Finding .................................................................... 41

\section{CHAPTER V DISCUSSION}

5.1 The Types of Multiple Intelligences Found in Fokus English Student Worksheet of Six Graders by Sindunta .............................. 73

5.1.1 The Finding of Types of Multiple Intelligences ............................. 73

5.1.2 The Types of Multiple Intelligences Found in Fokus English Worksheet in The First Theme entitled "Direction and Location".. 73

5.1.3 The Types of Multiple Intelligences Found in Fokus English Worksheet in The Second Theme entitled "Holiday" .....................

5.1.4 The Types of Multiple Intelligences Found in Fokus English Worksheet in The Third Theme entitled "Describing People and Object". 
5.1.5 The Types of Multiple Intelligences Found in Fokus English Worksheet in The Fourth Theme entitled "Shopping"

5.1.6 The Types of Multiple Intelligences Found in Fokus English Worksheet in The Fourth Theme entitled "Ownership"

5.1.7 The Types of Multiple Intelligences Found in Fokus English Worksheet in The Sixth Theme entitled "Folk Tales"

5.1.8 The Types of Multiple Intelligences Found in Fokus English Worksheet in The Seven Theme entitled "Government"

5.1.9 The Types of Multiple Intelligences Found in Fokus English Worksheet in The Eight Theme entitled "Order and Request" ......

5.1.10 The Types of Multiple Intelligences Found in Fokus English Worksheet in The Nine Theme entitled "Health and Hospital" ....

5.1.11 The Types of Multiple Intelligences Found in Fokus English Worksheet in The Ten Theme entitled "Earth and Planet"

5.1.12 The Types of Multiple Intelligences Found in Fokus English Worksheet in The eleven Theme entitled "Feelings"

5.1.13 The Types of Multiple Intelligences Found in Fokus English Worksheet in The Twelve Theme entitled "Tourism"

5.2 The Analyzing of Multiple Intelligences in Fokus English Student Worksheet of Six Graders by Sindunta

5.2.1 Analyzing of English Student Worksheet Facilitates The Types of Multiple Intelligences in Fokus Worksheet about "Directions and Locations".

5.2.2 Analyzing of English Student Worksheet Facilitates The Types Of Multiple Intelligences in Fokus Worksheet One about" Holiday"..

5.2.3 Analyzing of English Student Worksheet Facilitates The Types of Multiple Intelligences in Fokus Worksheet about" Describing People and Objects".

5.2.4 Analyzing of English Student Worksheet Facilitates The Types of Multiple Intelligences in Fokus Worksheet about" Shopping".......

5.2.5 Analyzing of English Student Worksheet Facilitates The Types of Multiple Intelligences in Fokus Worksheet about" Describing People and Objects"... 
5.2.6 Analyzing of English Student Worksheet Facilitates The Types of Multiple Intelligences in Fokus Worksheet about "Folks Tales"....

5.2.7 Analyzing of English Student Worksheet Facilitates The Types of Multiple Intelligences in Fokus Worksheet about "Government".

5.2.8 Analyzing of English Student Worksheet Facilitates The Types of multiple Intelligences in Fokus Worksheet about "Order and Request"

5.2.9 Analyzing of English Student Worksheet Facilitates The Types of Multiple Intelligences in Fokus Worksheet about "Health and Hospital"

5.2.10 Analyzing of English Student Worksheet Facilitates The Types of Multiple Intelligences in Fokus Worksheet about "Earth and Planets"

5.2.11 Analyzing of English Student Worksheet Facilitates The Types of Multiple Intelligences in Fokus Worksheet about "Feelings"

5.2.12 Analyzing of English Student Worksheet Facilitates The Types of Multiple Intelligences in Fokus Worksheet about "Tourism"

5.3 The Summary of The Analyzing Directions in The Fokus of English Student Worksheet by Sindunata.

\section{CHAPTER VI CONCLUSION AND SUGGESTIONS}

6.1 Conclusion

6.2 Suggestion 


\section{LIST OF TABLES}

Table

Page

3.1 Classifying The Types of Multiple Intelligences in Fokus English Students Worksheet

3.2 Analysing The Types of Multiple Intelligences in Fokus English Student Worksheet That Facilitate Those Intelligences

4.1.1 Theme 1 Direction and Location classification The Types of Multiple Intelligences in Fokus English Students Worksheet.

4.1.2 Theme 2 Holiday classification The Types of Multiple Intelligences in Fokus English Students Worksheet.

4.1.3 Theme 3 Describing People and Objects classification The Types of Multiple Intelligences in Fokus English Students Worksheet.....

4.1.4 Theme 4 shopping classification The Types of Multiple Intelligences in Fokus English Students Worksheet.

4.1.5 Theme 5 Ownership classification The Types of Multiple Intelligences in Fokus English Students Worksheet.

4.1.6 Theme 6 Folk Tales classification The Types of Multiple Intelligences in Fokus English Students Worksheet.

4.1.7 Theme 7 Government classification The Types of Multiple Intelligences in Fokus English Students Worksheet.

4.1.8 Theme 8 Order and Request classification The Types of Multiple Intelligences in Fokus English Students Worksheet.

4.1.9 Theme 9 Health and Hospital classification The Types of Multiple Intelligences in Fokus English Students Worksheet.

4.1.10 Theme 10 Earth and Planets classification The Types of Multiple Intelligences in Fokus English Students Worksheet.

4.1.11 Theme 11 Feelings classification The Types of Multiple Intelligences in Fokus English Students Worksheet.

4.1.12 Theme 12 Tourism classification The Types of Multiple Intelligences in Fokus English Students Worksheet.

4.1.13 The Summary of Classification The Types of Multiple Intelligences in The Fokus English Student Worksheet 
4.2.1 Theme 1 Directions and Locations Analyzing of English Student Worksheet Facilitates the Types of Multiple Intelligences in Fokus Worksheet

4.2.2 Theme 2 Holiday Analyzing of English Student Worksheet Facilitates the Types of Multiple Intelligences in Fokus Worksheet

4.2.3 Theme 3 Describing People and Object Analyzing of English Student Worksheet Facilitates the Types of Multiple Intelligences in Fokus Worksheet

4.2.4 Theme 4 Shopping Analyzing of English Student Worksheet Facilitates the Types of Multiple Intelligences in Fokus Worksheet.

4.2.5 Theme 5 Ownership Analyzing of English Student Worksheet Facilitates the Types of Multiple Intelligences in Fokus Worksheet.

4.2.6 Theme 6 Folk Tales Analyzing of English Student Worksheet Facilitates The Types of Multiple Intelligences in Fokus Worksheet.

4.2.7 Theme 7 Government Analyzing of English Student Worksheet Facilitates The Types of Multiple Intelligences in Fokus Worksheet.

4.2.8 Theme 8 Order and Request Analyzing of English Student Worksheet Facilitates The Types of Multiple Intelligences in Fokus Worksheet

4.2.9 Theme 9 Health and Hospital Analyzing of English Student Worksheet Facilitates The Types of Multiple Intelligences in Fokus Worksheet

4.2.10 Theme 10 Earth and Planets Analyzing of English Student Worksheet Facilitates the Types of Multiple Intelligences in Fokus Worksheet

4.2.11 Theme 11 Feelings Analyzing of English Student Worksheet Facilitates the Types of Multiple Intelligences in Fokus Worksheet.

4.2.12 Theme 12 Tourism Analyzing of English Student Worksheet Facilitates the Types of Multiple Intelligences in Fokus Worksheet. 